\title{
Happiness as Surplus or Freely Available Energy
}

\author{
Matthew T. Gailliot \\ University of Albany, Albany, USA \\ Email: mgailliot@gmail.com \\ Received March 24 $4^{\text {th }}, 2012$; revised May $7^{\text {th }}, 2012$; accepted June $8^{\text {th }}, 2012$
}

\begin{abstract}
This paper presents a literature review that indicate happiness as a state of freely available or surplus energy. Happiness is associated with good metabolism and glucose levels, fewer demands (from parenting, work, difficult social relationships, or personal threats), and goal achievement, as well as increased ease of processing, mental resources, social support, and monetary wealth. Each of these either provide or help conserve energy.
\end{abstract}

Keywords: Happiness; Emotion; Energy; Efficiency

\section{Introduction}

A focus on energy could be a powerful psychological perspective. People are organisms made of metabolic energy, and life can be viewed as a process of attaining and managing metabolic energy. Some work indicates that evolution selected on tendencies to attain increasingly larger amounts of energy (e.g., sugar, oil) from the environment and to use that energy efficiently (e.g., modern technology, Gilliland, 1978; Lotka, 1922; Odum, 1995). From this view, having and controlling energy should be associated with feeling good-one is fulfilling an evolved tendency — whereas lacking energy should feel bad.

The current work presents the theory that happiness is a state of having freely available or surplus energy (i.e., when energy availability exceeds demands). Processes that create or sustain this surplus are concomitant with happiness. The paper provides an in-depth review of the relevant literature on happiness and presents an experimental test of one hypothesis derived from the theory - that displays of happiness signal that one has expendable energy. The purpose of the review is to present a novel theory of happiness that advances research on and understanding of the topic and that synthesizes and links disparate research topics.

Energy relevant to happiness can take two forms. One is biological, metabolic energy (e.g., glucose). All cells in the body use metabolic energy. When metabolite supply exceeds demand, there is a surplus. The theory is that people are less happy when metabolic energy is low.

The other forms of energy relevant to happiness are seconddary sources of metabolic energy - sources that provide or conserve metabolic energy. These include social relationships (e.g., friends give food to one another and facilitate effortful coping) and technology (e.g., modern transportation conserves mechanical energy used for walking, computers reduce metabolic energy needed for memory because they preserve information). Secondary sources of energy are posited to be associated with happiness because they increase the likelihood of surplus energy.

\section{Happiness as Concomitant with Available Energy-A Review of the Happiness Literature}

Many studies link happiness with available energy. People generally associate happiness more with energy than a lack thereof. Energetic music (e.g., higher pitch tones, faster tempos, ascending scales) has been rated as happier than less energetic music (Collier \& Hubbard, 2001a, 2001b). Words indicative of happiness tend to reflect having energy to a greater extent than words less indicative of happiness (Storm, 1996).

Happy people tend to be more energetic, excited, and zestful than less happy people (Block \& Kremen, 1996; Csikszentmihalyi \& Hunter, 2003; Klohnen, 1996; Park \& Peterson, 2006; Peterson, Ruch, Beermann, Park, \& Seligman, 2007; Ryan \& Frederick, 1997). Happiness is associated with increased activity (Csikszentmihalyi \& Hunter, 2003; Veenhoven, 1988). One study found that watching a video that induced joy (v fear or anger) increased the number of activities in which participants wanted to engage (Fredrickson \& Branigan, 2004). Men in one study talked more to a female after having seen stimuli that increased positive (v negative) mood (Cunningham, 1988). Another study found that cricket players who were happy (v less happy) displayed more energy, enthusiasm, focus, and confidence (Totterdell, 1999).

Increased extraversion, often associated with energetic behavior, has strong links to happiness (Brebner, Donaldson, Kirby, \& Ward, 1995; Cheng \& Furnham, 2002; Francis, 1998; Francis, Brown, Lester, \& Philipchalk, 1998; Francis \& Lester, 1997; Furnham \& Cheng, 1999; Hills \& Argyle, 2001; Jopp \& Rott, 2006; Lu \& Shih, 1997), even when making comparisons across nations (Steel \& Ones, 2002). Extraversion is associated with increased approach, and likewise happiness has been linked to increased engagement and sociability (Csikszentmihalyi \& Hunter, 2003; Peterson et al., 2007).

Depression is strongly and negatively associated with happiness (APA, 1994; Joseph \& Lewis, 1998; Kammann \& Flett, 1983; Matsubayashi et al., 1992; McGreal \& Joseph, 1993). A defining feature of depression is low energy or tiredness (McGillivray \& McCabe, 2007; Naarding et al., 2007).

Even perceptual biases suggest happiness as a state of surplus energy. Participants induced into a happy (v sad) mood perceived a hill as less steep (Riener, Stefanucci, Proffitt, \& Clore, 2003). The idea is that happy participants had sufficient energy to ascend the hill, and so it appeared less steep.

Happiness generally has thus been linked to having available 
energy, whereas low happiness (or sadness) has been linked to low energy. This pattern is mirrored in work on primary and secondary sources of metabolic energy.

\section{Primary Energy}

\section{Metabolic Energy}

Metabolic energy is the primary energy through the use of which all thought and action occur. Evidence indicates that happiness is reduced when the metabolic energy of glucose is low or its use is impaired, whereas happiness is higher when adequate amounts of usable glucose are available.

Bad or depressed moods are more common when glucose is low (Barglow et al., 1984; Benton \& Owens, 1993; Hepburn, Deary, MacLeod, \& Frier, 1996; Taylor \& Rachman, 1988; Wredling, Theorell, Roll, Lins, \& Adamson, 1992; YaryuraTobias \& Neziroglu, 1975; cf. Reid \& Hammersley, 1995; Scholey \& Kennedy, 2004) and among people with (v without) diabetes, who process glucose less effectively and are prone to experience hypoglycemia (e.g., Eren, Erdi, \& Özcankaya, 2003; Fabrykant \& Pacella, 1948; Fris \& Nanjundappa, 1986; Gonder-Frederick, Cox, Bobbitt, \& Pennebaker, 1989; Lustman, Griffith, Clouse, \& Cryer, 1986; Mueller, Heninger, \& McDonal, 1968; Popkin, Callies, Lentz, Colon, \& Sutherland, 1988; Van Pragg \& Leijnse, 1965; Wells, Golding, \& Burnam, 1989; Wilson, 1951). A glucose clamp (v control device), which reduces glucose levels, has been found to worsen mood (Gold, MacLeod, Deary, \& Frier, 1995; McCrimmon, Frier, \& Deary, 1999), as has skipping breakfast (Smith, Clarka, \& Gallaghera, 1999). Conversely, glucose drinks (v placebos) have been found to improve mood (Benton, Brett, \& Brain, 1987; Benton \& Owens, 1993).

Research on the symptoms of premenstrual syndrome (PMS) provides converging evidence. Metabolic energy use by the ovaries increases during PMS (e.g., Aschoff \& Pohl, 1970; Bisdee \& James, 1983; Bisdee, James, \& Shaw, 1989; Dalton, 1999; Hessemer \& Bruck, 1985; Landgren, Unden, \& Diczfalusy, 1980; Mayo, 1997; Solomon, Kurzer, \& Calloway, 1982; Webb, 1981, 1986), thereby reducing the likelihood of energy surplus. A large body of evidence links conclusively PMS to more negative mood (Bailey \& Cohen, 1999; Baker, Best, Manfredi, Demers, \& Wolf, 1995; Bloch, Schmidt, \& Rubinow, 1997; Dalton, 1999; Evans, Haney, Levin, Foltin, \& Fischman, 1998; George, 2009; Hartlage \& Arduino, 2002; Limosin, Gorwood, \& Ades, 2001; Natale \& Albertazzi, 2006; Rapkin, 2003; Rubinow et al., 1986; Symonds, Gallagher, Thompson, \& Young, 2004; Zhao, Wang, Qu, \& Wang 1998).

Using self-control has been found to decrease glucose in the bloodstream (Fairclough \& Houston, 2004; Gailliot et al., 2007a; Gailliot, 2009a). Using self-control therefore might worsen mood. Individual studies have largely failed to find evidence that using self-control worsens mood, yet a metaanalysis of over 600 participants found a small effect of selfcontrol worsening mood (Gailliot \& Vohs, 2009).

If metabolic energy improves mood, then people might eat so as to escape negative moods. Indeed, depression increases food cravings (Dye, Warner, \& Bancroft, 1995) and eating is a typical response to relieve personal distress (Tice, Baumeister, Shmueli, \& Muraven, 2006).

Physiological states, aside from glucose, related to metabolic energy distribution might also relate to mood. Pleasant stimuli (e.g., odors, pictures) reduced cortisol (Barak, 2006), which functions partly to increase blood-glucose. Another study demonstrated that happiness ( $v$ anger or anxiety) predicted lower blood pressure (James, Yee, Harshfield, Blank, \& Pickering, 1986). Increased blood pressure can be concomitant with increased metabolite distribution.

Some studies examining energy use in the brain also are consistent with a link between happiness and surplus energy. Neuroscience evidence indicates that sadness can increase brain energy use, whereas happiness can decrease it (Baxter et al., 1989; George et al., 1995).

Self-control allows for emotional coping (e.g., regulating moods so as to increase happiness, Baumeister, Bratslavsky, Muraven, \& Tice, 1998; Finkel \& Campbell, 2001; Gailliot, Schmeichel, \& Baumeister, 2006; Gailliot, Schmeichel, \& Maner, 2006; Muraven \& Slessareva, 2003; Muraven, Tice, \& Baumeister, 1998; Schmeichel, Demaree, Robinson, \& Pu, 2005; Schmeichel, Vohs, \& Baumeister, 2003; Shamosh \& Gray, 2006; Vohs, Baumeister, \& Ciarocco, 2005) and is intrinsically tied with glucose metabolism (DeWall, Baumeister, Gailliot, \& Maner, 2008; DeWall, Gailliot, Deckman, \& Bushman, 2009; Fairclough \& Houston, 2004; Gailliot, 2008, 2009a, 2009b, 2009d, 2009e, in press; Gailliot et al., 2007; Gailliot \& Baumeister, 2007; Gailliot, Hildebrandt, Eckel, \& Baumeister, 2009; Gailliot, Peruche, Plant, \& Baumeister, 2009; Masicampo $\&$ Baumeister, 2008). A survey across nations indicated that the ability to cope is a primary determinant of happiness (Haller \& Hadler, 2006).

Other work further implicates self-control, and hence metabolism, as linking happiness to energy. Noise impairs selfcontrol (Muraven \& Baumeister, 2000) perhaps via metabolite depletion (Gailliot \& Baumeister, 2007). Likewise, noise pollution predicts reduced happiness (Weinhold, 2008). Others have argued that happiness rests crucially on the regulation and control of drives, impulses, and objects (Furnham \& Petrides, 2003; Mukherjee \& Basu, 2008), which is akin to self-control.

The composition of neurotransmitters can be used to test whether happiness is associated with increased energy. The prediction is that neurotransmitters associated with happiness contain more useable energy than do other neurotransmitters. Neurons fire via the use of adenosine triphosphate (ATP) derived from breaking carbon-to-carbon bonds. Dopamine is positively associated with happiness (Bressan \& Crippa, 2005; Drevets et al., 2001), and it contains more carbon than do other neurotransmitters, such as acetylcholine, $\boldsymbol{\gamma}$-Aminobutyric acid (GABA), or glutamate (Wikipedia, 2012), thus supporting the prediction.

\section{Demands on Metabolic Energy}

That which uses more energy can be considered a demand on metabolic energy, and that which uses more energy also reduces the likelihood of there being freely available or surplus energy. Numerous studies link increased life demands, therefore entailing increased energy use (Fairclough \& Houston, 2004), to reduced happiness. Happiness will often be associated with low energy and high demands because these are times when a surplus of energy is less likely.

Being a parent demands a lot of energy (e.g., obtaining money). It also reduces happiness (Glenn \& McLanahan, 1982; Glenn \& Weaver, 1978; McLanahan \& Adams, 1987; Nicolson, 1999; White, Booth, \& Edwards, 1986). 
Work often is effortful and entails overriding intrinsic, so as to meet extrinsic, motivations (Gordijn, Hindriks, Koomen, Dijksterhuis, \& Van Knippenberg, 2004). When work is less demanding - such as toward the weekend (Csikszentmihalyi \& Hunter, 2003; Gallup, 2008; Mihalcea \& Liu, 2006) or when more leisure time is afforded (Cameron, 1975; Csikszentmihalyi \& Hunter, 2003; Easterlin, 2003; Tella \& MacCulloch, 2007; Tkach \& Lyubomirsky, 2006; Yu et al., 2002)-happiness is greater. The effort of caring for one with a disability likewise predicts reduced happiness (Easterlin, 2003; Eriksson, Tham, \& Fugl-Meyer, 2005; Marinic \& Brkljacic, 2008). Demanding marriages reduce happiness relative to those that do not $(\mathrm{Lu} \&$ Shih, 1997; Orden \& Bradburn, 1969; Pina \& Bengston, 1993; Rabin \& Shapira-Berman, 1997; Ward, 1993), as do difficult social relationships relative to easier ones (e.g., such as through the conflict of worldviews, Burleson, 1994; Ortega, Whitt, \& Williams, 1988; Pickford, Signori, \& Rempel, 1966; Suitor, 1987; Welsch, 2008).

Other demands have also been linked to reduced happiness. Physical attractiveness among women, for whom good looks especially save energy in pursuit of attracting and attaining high quality mates, but not men has been found to predict increased happiness (Mathes \& Kahn, 1975). Homeless people (v people who have a home) are less happy (Biswas \& Diener, 2006). Social projects that reduce living demands likewise increase happiness (Moller \& Jackson, 1997).

Happiness can be considered the opposite of experiencing personal threat, and threat occurs when demands exceed available resources to cope (Blascovich \& Tomaka, 1996; Blascovich \& Mendes, 2000). Happiness therefore should involve having resources or experiencing low demands. Mortality is more threatening when metabolic energy is low (Gailliot, $2009 \mathrm{~b}$, in press), and mortality salience might reduce glucose (Gailliot et al., 2007). Greater religiosity has been found to reduce the threat, and therefore costs, of mortality salience (Jonas \& Fischer, 2006), and therefore should be associated with an increased likelihood of surplus energy (due to reduced costs coping with mortality). Connecting this possibility to happiness, religion is associated with greater happiness (Cameron, 1975; French \& Joseph, 1999; Francis \& Lester, 1997; Lelkes, 2005; Swinyard, Kau, \& Phua, 2001; cf. Lewis, Lanigan, Joseph, \& Fockert, 1997; Lewis, Maltby, \& Burkinshaw, 2000). Threat occurring from being bullied or sexually harassed among children predict reduced happiness (Gibbs \& Sinclair, 2000), as does greater social anxiety (Neto, 2001).

Some theorists have argued that happiness is reduced because life is more demanding due to our living in a world that is radically different from the one in which our ancestors evolved (Buss, 2000; Grinde, 2002). Hence, metabolically expensive (Fairclough \& Houston, 2004; Gailliot et al., 2007; Gailliot \& Baumeister, 2007) regulation systems are overactive (Nesse, 2004).

\section{Goals}

A goal is a metabolic demand ongoing for some time. A goal thus can be represented as a process of metabolic energy attainment and use (e.g., each time a dieter sees a piece of cake, he or she effortfully uses self-control to avoid it, a person with a physical fitness goal regularly expends metabolic energy every workout). When a goal ceases or is relinquished, energy previously committed to the goal becomes freely available, surplus energy. Such dynamics should influence happiness.

Indeed, meeting a goal, or goals, can increase happiness (Diener \& Lucas, 2000; Haybron, 2008; Kasser \& Ryan, 1993). Hence, satisfaction with specific life domains predicts increased happiness (Michalos, 1980). Happiness is strongly influenced by discrepancies between what one has and wants (Michalos, 1983; Tsou \& Liu, 2001), perhaps because of the extent to which one is motivated or has formed goals to obtain more. The goal of maximizing ( $\mathrm{v}$ nonmaximizing) - in which people attempt to choose the very best among every option - might also reduce happiness (Schwartz et al., 2002).

\section{Mental Resources and Processing Fluency}

Biological resources - metabolic energy —often has been referred to as "mental resources" in the social sciences, though the construct overlaps with actual metabolic energy (Gailliot et al., 2007; Gailliot \& Baumeister, 2007; Gailliot, 2009c). Findings on mental resources and ease of processing are consistent with the idea that happiness is concomitant with energy.

Happy people appear to have more mental resources than less happy people, such that they are more creative, mindful, and optimistic (Basso et al., 1996; Derryberry \& Tucker, 1994; Fredrickson \& Branigan, 2004; Isen et al., 1987). They display broader thought and attention and are more open to information (Estrada et al., 1997). Happy (vs unhappy) children have been found to delay gratification longer (Moore, Clyburn, \& Underwood, 1976; Schwarz \& Pollack, 1977). Negative moods seem to impair self-control (Leith \& Baumeister, 1996; Tice, Bratslavsky, \& Baumeister, 2001). Positive affect has been found to replenish self-control when it is fatigued (Tice et al., 2006). One contradictory finding was that a happiness induction increased stereotype use (Bodenhausen, Kramer, \& Susser, 1994), suggesting reduced mental resources (Devine, 1989). It could be that happy people have more energy and mental resources, though they might not always willingly expend their energy or resources. Hence, when participants were held accountable for their stereotype use, happiness did not increase stereotype use (Bodenhausen et al., 1994).

Stimuli that take less energy to process - such as those that are familiar - should be liked more than stimuli that take more energy to process, consistent with the link between having freely available energy and happiness. In support of this, stimuli that are easier to process and familiar are liked more than other stimuli, and these stimuli have been found to produce less brain activation (i.e., use less energy) (Bornstein, 1989; Cacioppo \& Winkielman, 2001; Desimone, Miller, Chelazzi, \& Lueschow, 1995; Haber \& Hershenson, 1965; Harrison, 1977; Jacoby \& Dallas, 1981; Whittlesea, Jacoby, \& Girard, 1990; Witherspoon \& Allan, 1985; Zajonc, 1968, 2001, 2002). People also like more stimuli that are prototypical or symmetrical (Berlyne, 1974; Halberstadt \& Rhodes, 2000; Langlois \& Roggman, 1990; Martindale \& Moore, 1988; Rhodes \& Tremewan, 1996) possibly because they are processed faster and more efficiently (Checkosky \& Whitlock, 1973; Johnstone, 1994; Palmer, 1991; Posner \& Keele, 1968; Rosch \& Lloyd, 1978) which should reduce energy use (Mulder, 1986). Anticipated ( $\mathrm{v}$ unanticipated) information has been found to be processed faster and hence easier, and to be more pleasant (Whittlesea, 1993). Likewise, factors that facilitate the processing of stimuli have been found to increase liking for the stimuli (Reber, Winkielman, \& Schwarz, 1998). Numbers are more easily proc- 
essed in Chinese than in English, and math tends to be better liked among Chinese than English speakers (Gladwell, 2009).

\section{Secondary Energy}

Factors that provide energy or reduce its use (sources of secondary energy) also suggest a connection between happiness and having energy. Two examples are social support and monetary wealth.

\section{Social Support}

Social support can provide energy or reduce its use in several ways. People give one another food. They also save energy in many ways for one another, such as by helping one another, assisting in coping with stress, or providing resources while requiring relatively little work (e.g., parents giving clothing to their children).

Ample evidence demonstrates that people are happier with better social support or more social involvement (Baumeister \& Leary, 1995; Booth, 1992; Brim, 1974; Chan \& Lee, 2006; Gundelach \& Kreinar, 2004; Jopp \& Rott, 2006; Kehle \& Bray, 2003; Lane, 1994, 2000; Lu, 1999; Lu, Shih, Lin, \& Ju, 1997; Natvig, Albrektsen, \& Qvarnstrom, 2003; Neto, 2001; North, Holahan, Moos, \& Cronkite, 2008; Perneger, Hudelson, \& Bovier, 2004; Phillips, 1967; Ryuichi et al., 1999; Singh et al., 2004; Uchida, Norasakkunkit, \& Kitayama, 2004). Happiness is positively associated with self-esteem (Baumeister, Campbell, Krueger, \& Vohs, 2003), and self-esteem reflects belongingness (Leary \& Baumeister, 2000). People report seeking social contact so as to increase their happiness (Tkach \& Lyubomirsky, 2006). Married people tend to be happier than unmarried people (Cid, Ferres, \& Rossi, 2008; Mookherjee, 1998; Stack \& Eshleman, 1998). Religious institutions can serve as a source of social support, and religious involvement predicts increased happiness (Cameron, 1975; Francis \& Lester, 1997; French \& Joseph, 1999; Lelkes, 2005; Swinyard, Kau, \& Phua, 2001; cf. Lewis, Lanigan, Joseph, \& Fockert, 1997; Lewis, Maltby, \& Burkinshaw, 2000). Likewise, the end of social relationships and death greatly reduce happiness (Ballas \& Dorling, 2007; Oswald \& Powdthavee, 2008).

\section{Monetary Wealth}

Money is another source of secondary energy. Money can be used to acquire metabolic energy (e.g., buy food) and it can also save energy (e.g., paying for a taxi rather than walking, hiring an accountant to do one's taxes, using air conditioning rather than sweating in the heat). People with money can have a more leisurely, effortless life than can those without. Money therefore should be associated with a greater likelihood of having available energy.

Ample research demonstrates a positive correlation between wealth and happiness. Across both nations and individuals, wealth predicts happiness (Biswas-Diener \& Diener, 2006; Cid, Ferres, \& Rossi, 2008; Diener, Horwitz, \& Emmons, 1985; Easterlin, 1995, 2001; Gardner \& Oswald, 2001; Gerdtham \& Johannesson, 2002; Hagerty \& Veenhoven, 2003; Johnson \& Krueger, 2006; Mookherjee, 1998; Namazie \& Sanfey, 1998; North, Holahan, Moos, \& Cronkite, 2008; Rogers \& DeBoer, 2001; Saunders, 2009; Schyns, 1998; Stack \& Eshleman, 1998; Steel \& Ones, 2002; Tella \& MacCulloch, 2007; Tella, MacCulloch, \& Oswald, 2003; Tella, New, \& MacCulloch, 2007;
Shin \& Johnson, 1978; Veenhoven, 1991, 1995; World Bank, 1997; cf. Easterlin, 2005). Likewise, unemployment might lead to unhappiness (Booth \& Ours, 2007; Di Tella, MacCulloch, \& Oswald, 2001; Frey \& Stutzer, 2000; Graham \& Pettinato, 2001).

When people aspire for more than they have, however, money might not lead to happiness (Hagerty, 2000; Stutzer, 2004; Tsou \& Liu, 2001). This is consistent with the idea that happiness is reduced with increased demands or goals - in this case, to acquire more wealth.

\section{An Experimental Test-Displays of Happiness as Energetically Inefficient}

If happiness is concomitant with having available or surplus energy, then its expression may signal that one has expendable energy. Expressions of happiness may entail reduced efficiency.

Past work has found that depressed individuals conserve energy in their movements - they move relatively little (Fisch, Frey, \& Hirsbrunner, 1983; Griesinger, 1876; Kraepelin, 1913). Upon recovering from depression, people move more, more complexly, and more rapidly. This suggests that happiness might be negatively associated with the conservation of mechanical energy.

An experimental study showed that more participants who received a positive comment (e.g., "I like your shirt.") from an experimenter lifted their feet less efficiently while walking upstairs than did participants who received a neutral comment (i.e., "This is Hall C."), $\chi^{2}=2.78, p<.05$ (one-tailed; see Figure 1).

\section{General Discussion}

A review of the literature on happiness and an experimental test provided general support for the idea that happiness is a state in which one has freely available or surplus energy. This pattern emerged from work on a variety of topics, including metabolism, demands (parenting, work, difficult social relationships, personal threat), goals, ease of processing and liking,

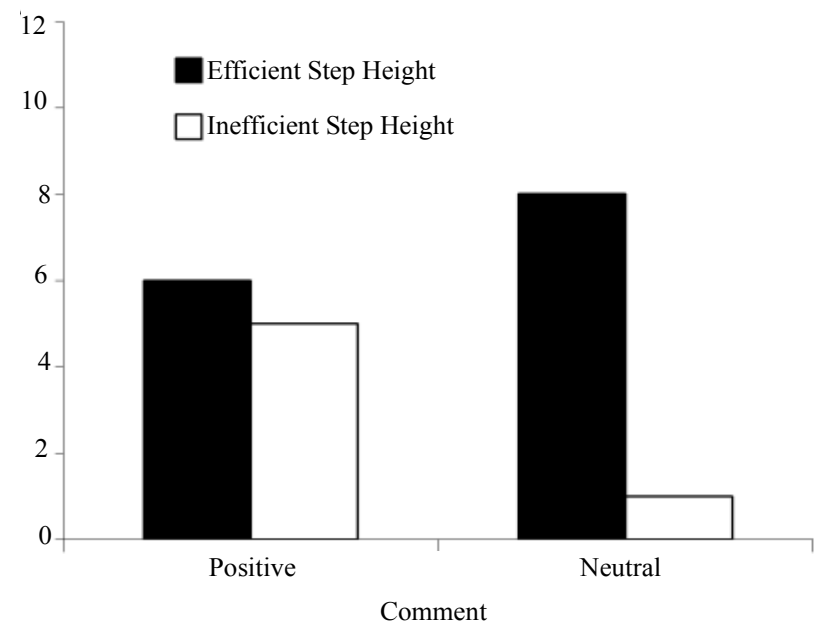

Figure 1.

Number of people who exhibited either efficient or inefficient step height as a function of having received either a compliment or neutral statement. 
mental resources, social support, and monetary wealth. The theory brings together work across several different disciplines, including neuroscience, endocrinology, social psychology, economics, sociology, and biology.

The theory of happiness and energy should help explain findings on happiness other than those reviewed. Happiness has been found to predict future success (e.g., in marriage, friendship, wealth, work, and health, Lyubomirsky, King, \& Diener, 2005). To the extent that happiness represents having energy, then being capable of energy-demanding activities (e.g., resolving difficulties with a spouse) should lead to lead to future success.

One seemingly inconsistent finding may be that hyperglycemia (i.e., when blood-glucose levels are especially high) is not associated with happiness, though there is ample energy in the bloodstream. Hyperglycemia might not be linked to happiness because it may reduce the flow of glucose to the brain.

One might conclude that people should rarely expend energy (e.g., sit on the couch all day) because they generally seek happiness. Though this can occur (e.g., passivity is increasingly common in modern society), people clearly expend their energy on a regular basis. Conservation might be reduced because one must use energy to obtain energy (e.g., work 40 hours each week to ensure an adequate food supply) and because people have goals less clearly related to energy (e.g., reproductive goals). Happiness is having surplus energy in the context of other meanings and values in life.

One strength of the proposed theory is that it suggests many novel hypotheses. All else being equal, events that provide energy will tend to produce greater happiness than will events that provide less energy or take away energy. People are happier if there exists the potential to use taxi rides rather than to always walk. The inefficient acts in which happy people engage (e.g., play behavior) might be more likely to be perceived as pointless or wasteful to others. Happy people expend energy more liberally, and so others might not perceive the value of these behaviors. The relationship between happiness and energy could be cyclical. Having energy allows one to more easily ensure future happiness. For example, a happy person at work might cheer up another coworker by giving flowers, increasing the likelihood that the coworker will reward the person in the future. Approaches to increasing happiness should include those that free up metabolic resources or provide resources, such as those that alleviate demands. Chronically unhappy individuals might have tendencies to overcommit themselves and rarely experience energy surplus.

In demanding situations, people might expect happy people to be less happy and to use their energy to help. Displays of happiness should be perceived negatively when energy is wasted. Factors should influence happiness partly to the extent that they create metabolic demands. For example, an argument that brings to mind new challenges should decrease happiness, whereas an argument that ends a demanding and draining relationship should reduce happiness to a lesser extent or even increase happiness. Diabetes and problems with glucose are linked to being less happy (see above). Other metabolic disorders might therefore be related to happiness. Factors that might increase the use of glucose include high processing loads, novelty, time pressure, and multitasking (Mulder, 1986). These same factors might reduce happiness. Happiness might arise from having too much information to process, being overwhelmed with novelty or experiencing too much change, lack- ing sufficient time to complete goals, or trying to do too much.

Happiness should be higher across the lifespan during times when people have more energy. Some studies have found that younger people tend to be happier than older people (Chang, 2007; Easterlin, 2006; Gerdtham \& Johannesson, 2002; Holahan, Holahan, Velasquez, \& North, 2008; Selim, 2008; cf. Fugl-Meyer, Branholm, \& Fugl-Meyer, 1991), and they also tend to have more (primary) energy. Whether energy is available for use might be key in determining happiness. Fat people have more stored energy than thin people, yet they might not be happier partly because good physical fitness enhances the distribution of metabolites throughout the body.

Happiness might increase from terminating goals and not only from achieving them. Abandoning a failed goal, for instance, might eventually increase happiness because one is able to use energy that otherwise would have been used toward goal pursuit.

Energy is concomitant with happiness. Happy people may signal their happiness by being less energetically efficient or expending more energy than needed. The happy person sings in the shower. Typical smiles may use more energy than typical frowns. And, as demonstrated-happiness puts an inefficient "pep in one's step".

\section{REFERENCES}

Alesina, A., Tella, R. D., \& MacCulloch, R. (2003). Inequality and happiness: Are Europeans and Americans different? Journal of Public Economics, 88, 2009-2042. doi:10.1016/j.jpubeco.2003.07.006

APA (American Psychiatric Association) (1994). Diagnostic and statistical manual of mental disorders. 4th Edition, Washington DC: American Psychiatric Association, 715-718.

Aschoff, J., \& Pohl, H. (1970). Rhythmic variations in energy metabolism. Federation Proceedings, 29, 1541-1542.

Bailey, J. W., \& Cohen, L. S. (1999). Prevalence of mood and anxiety disorders in women who seek treatment for premenstrual syndrome. Journal of Women's Health and Gender-Based Medicine, 8, 11811184. doi:10.1089/jwh.1.1999.8.1181

Baker, E. R., Best, R. G., Manfredi, R. L., Demers, L. M., \& Wolf, G. C. (1995). Efficacy of progesterone vaginal suppositories in alleviation of nervous symptoms in patients with premenstrual syndrome. Journal of Assisted Reproduction and Genetics, 12, 205-209. doi: $10.1007 / \mathrm{BF} 02211800$

Ballas, D., \& Dorling, D. (2007). Measuring the impact of major life events upon happiness. International Journal of Epidemiology, 36, 1244-1252. doi:10.1093/ije/dym 182

Barak, Y. (2006). The immune system and happiness. Autoimmunity Reviews, 5, 523-527. doi:10.1016/j.autrev.2006.02.010

Barglow, P., Hatcher, R., Edidin, D. V., \& Sloan-Rossiter, D. (1984). Stress and metabolic control in diabetes: Psychosomatic evidence and evaluation of methods. Psychosomatic Medicine, 46, 127-144.

Baumeister, R. F., Bratslavsky, E., Muraven, M., \& Tice, D. M. (1998). Ego depletion: Is the active self a limited resource? Journal of Personality and Social Psychology, 74, 1252-1265. doi:10.1037/0022-3514.74.5.1252

Baumeister, R. F., \& Leary, M. R. (1995). The need to belong: Desire for interpersonal attachments as a fundamental human motivation. Psychological Bulletin, 117, 497-529. doi:10.1037/0033-2909.117.3.497

Baumeister, R. F., Campbell, J. D., Krueger, J. I., \& Vohs, K. D. (2003). Does high self-esteem cause better performance, interpersonal success, happiness, or healthier lifestyles? Psychological Science in the Public Interest, 4, 1-44. doi:10.1111/1529-1006.01431

Benton, D., \& Owens, D. (1993). Is raised blood glucose associated with the relief of tension? Journal of Psychosomatic Research, 37, 1-13. doi:10.1016/0022-3999(93)90101-K

Benton, D., Brett, V., \& Brain, P. F. (1987). Glucose improves attention 
and reaction to frustration in children. Biological Psychology, 24, 95-100. doi:10.1016/0301-0511(87)90016-0

Berlyne, D. E. (1974). Studies in the new experimental aesthetics: Steps toward an objective psychology of aesthetic appreciation. Washington DC: Hemisphere.

Bisdee, J. T., James, W. P., \& Shaw, M. A. (1989). Changes in energy expenditure during the menstrual cycle. The Britsh Journal of Nutrition, 61, 187-199. doi:10.1079/BJN19890108

Bisdee, J. T., \& James, W. P. T. (1983). Whole body calorimetry studies in the menstrual cycle. New York: Fourth International Conference on Obesity.

Biswas-Diener, R., \& Diener, E. (2006). The subjective well-being of the homeless, and lessons for happiness. Social Indicators Research, 76, 185-205. doi:10.1007/s11205-005-8671-9

Bloch, M., Schmidt, P. J., \& Rubinow, D. R. (1997). Premenstrual syndrome: Evidence for symptom stability across cycles. American Journal of Psychiatry, 154, 1741-1746.

Bodenhausen, G. V., Kramer, G. P., \& Susser, K. (1994). Happiness and stereotypic thinking in social judgment. Journal of Personality and Social Psychology, 66, 621-632. doi:10.1037/0022-3514.66.4.621

Booth, A. L., \& Ours, J. C. V. (2007). Job satisfaction and family happiness: The part-time work puzzle. URL (last checked 21 May 2009). http://ssrn.com/abstract $=1138584$

Booth, R. (1992). An examination of the relationship between happiness, loneliness, and shyness in college students. Journal of College Student Development, 33, 157-162.

Bornstein, R. F. (1989). Exposure and affect: Overview and metaanalysis of research, 1968-1987. Psychological Bulletin, 106, 265289. doi:10.1037/0033-2909.106.2.265

Brebner, J., Donaldson, J., Kirby, N., \& Ward, L. (1995). Relationships between happiness and personality. Personality and Individual Differences, 19, 251-258. doi:10.1016/0191-8869(95)00022-X

Bressan, R. A., \& Crippa, J. A. (2005). The role of dopamine in reward and pleasure behaviour-Review of data from preclinical research. Acta Psychiatrica Scandinavic, 111, 14-21.

doi:10.1111/j.1600-0447.2005.00540.x

Brickman, P., \& Campbell, D. T. (1971). Hedonic relativism and planning the good society. In M. H. Appley (Ed.), Adaptation-level theory (pp. 287-305). New York: Academic Press.

Brim, J. A. (1974). Social network correlates of avowed happiness. The Journal of Nervous and Mental Disease, 158, 432-439. doi:10.1097/00005053-197406000-00006

Burleson, B. R. (1994). Thoughts about talk in romantic relationships: Similarity makes for attraction (and happiness, too). Communication Quarterly, 42, 259-273. doi:10.1080/01463379409369933

Buss, D. M. (2000). The evolution of happiness. American Psychologist, 55, 15-23. doi:10.1037/0003-066X.55.1.15

Cacioppo, J. T., \& Winkielman, P. (2001). Mind at ease puts a smile on the face: Psychophysiological evidence that processing facilitation elicits positive affect. Journal of Personality and Social Psychology, 81, 989-1000. doi:10.1037/0022-3514.81.6.989

Cameron, P. (1975). Mood as an indicant of happiness: Age, sex, social class, and situational differences. Journal of Gerontology, 30, 216224.

Chan, Y. K., \& Lee, R. P. L. (2006). Network size, social support and happiness in later life: A comparative study of Beijing and Hong Kong. Journal of Happiness Studies, 7, 87-112. doi:10.1007/s10902-005-1915-1

Chang, P. C. (2007). Demographic factors affecting happiness and the relations between happiness, job satisfaction, organizational commitment, and turnover intention. Thesis, Human Resource Management.

Checkosky, S. F., \& Whitlock, D. (1973). The effects of pattern goodness on recognition time in a memory search task. Journal of $E x-$ perimental Psychology, 100, 341-348. doi:10.1037/h0035692

Cheng, H., \& Furnham, A. (2002). Personality, self-esteem, and demographic predictions of happiness and depression. Personality and Individual Differences, 34, 921-942.

doi:10.1016/S0191-8869(02)00078-8

Cid, A., Ferres, D., \& Rossi, M. (2008). Testing happiness hypotheses among the elderly. Economy Notebooks, 27, 23-45.

Collier, W. G., \& Hubbard, T. L. (2001a). Judgments of happiness, brightness, speed and tempo change of auditory stimuli varying in pitch and tempo. Psychomusicology, 17, 36-55. doi: $10.1037 / \mathrm{h} 0094060$

Collier, W. G., \& Hubbard, T. L. (2001b). Musical scales and evaluations of happiness and awkwardness: Effects of pitch, direction, and scale mode. American Journal of Psychology, 114, 355-375. doi: $10.2307 / 1423686$

Csikszentmihalyi, M., \& Hunter, J. (2003). Happiness in everyday life: The uses of experience sampling. Journal of Happiness Studies, 4, 185-199. doi:10.1023/A:1024409732742

Cunningham, M. R. (1988). Does happiness mean friendliness? Personality and Social Psychology Bulletin, 14, 283-297. doi: $10.1177 / 0146167288142007$

Dalton, K. (1999). Preliminary communication-does hormonal contraception increase the risk of postnatal psychosis? The British Journal of Family Planning, 24, 172.

Desimone, R., Miller, E. K., Chelazzi, L. \& Lueschow, A. (1995). Multiple memory systems in the visual cortex. In M. S. Gazzaniga (Ed.), The cognitive neurosciences (pp. 475-490). Cambridge, MA: MIT Press.

Devine, P. G. (1989). Stereotypes and prejudice: Their automatic and controlled components. Journal of Personality and Social Psychology, 56, 5-18. doi:10.1037/0022-3514.56.1.5

DeWall, C. N., Baumeister, R. F., Gailliot, M. T., \& Maner, J. K. (2008). Depletion makes the heart grow less helpful: Helping as a function of self-regulatory energy and genetic relatedness. Personality and Social Psychology Bulletin, 34, 1653-1662. doi: $10.1177 / 0146167208323981$

DeWall, C. N., Deckman, T., Gailliot, M. T., \& Bushman, B. J. (2009). Sweetened blood cools hot tempers: Physiological self-control and aggression. Aggressive Behavior, 37, 1, 73-80. doi:10.1002/ab.20366

Di Tella, R., MacCulloch, R. J., \& Oswald, A. J. (2001). Preferences over inflation and unemployment: Evidence from surveys of happiness. The American Economic Review, 91, 335-341. doi:10.1257/aer.91.1.335

Diener, E., Horwitz, J., \& Emmons, R. A. (1985). Happiness of the very wealthy. Social Indicators Research, 16, 263-274. doi:10.1007/BF00415126

Diener, E., Sandvik, E., \& Pavot, W. (1991). Happiness is the frequency, not the intensity of positive versus negative affect. In F. Strack, M. Argyle, \& N. Schwarz (Eds.), Subjective well-being: An interdisciplinary perspective. Oxford: Pergamon Press.

Drevets, W. C., Gautier, C., Price, J. C., Kupfer, D. J., Kinahan, P. E., Grace, A. A. et al. (2001). Amphetamine-induced dopamine release in human ventral striatum correlates with euphoria. Biological Psychiatry, 49, 81-96. doi:10.1016/S0006-3223(00)01038-6

Dye, L., Warner, P., \& Bancroft, J. (1995). Food craving during the menstrual cycle and its relationship to stress, happiness of relationship and depression: A preliminary group. Journal of Affective Disorders, 34, 157-164. doi:10.1016/0165-0327(95)00013-D

Easterlin, R. A. (1995). Will raising the incomes of all increase the happiness of all? Journal of Economic Behavior and Organization, 27, 35-47. doi:10.1016/0167-2681(95)00003-B

Easterlin, R. A. (2001). Income and happiness: Towards a unified theory. The Economic Journal, 111, 465-484. doi:10.1111/1468-0297.00646

Easterlin, R. A. (2003). Explaining happiness. Proceedings of the National Academy of Sciences, 100, 11176-11183. doi:10.1073/pnas.1633144100

Easterlin, R. A. (2003). Happiness of women and men in later life: Nature, determinants, and prospects. In M. J. Sirgy (Ed.), Advances in Quality-of-Life Theory and Research (pp. 13-25). The Netherlands: Kluwer Academic.

Easterlin, R. A. (2005). Feeding the illusion of growth and happiness: A reply to Hagerty and Veenhoven. Social Indicators Research, 74, 429-443. doi:10.1007/s11205-004-6170-z

Easterlin, R. A. (2006). Life cycle happiness and its sources: Intersections of psychology, economics, and demography. Journal of Economic Psychology, 27, 463-482. doi:10.1016/j.joep.2006.05.002 
Eren, I., Erdi, Ö., \& Özcankaya, R. (2003). Relationship between blood glucose control and psychiatric disorders in type II diabetic patients. Turk Psikiyatri Dergisi, 14, 184-191.

Eriksson, O. T. G., Tham, K., \& Fugl-Meyer, A. R. (2005). Couple's happiness and its relationship to functioning in everyday life after brain injury. Scandinavian Journal of Occupational Therapy, 12, 4048. doi: $10.1080 / 11038120510027630$

Evans, S. M., Haney, M., Levin, F. R., Folton, R. W., \& Fischman, M. W. (1998). Mood and performance changes in women with premenstrual dysphoric disorder: Acute effects of alprazolam. Neuropsychopharmacology, 19, 499-516. doi:10.1016/S0893-133X(98)00064-5

Fabrykant, M., \& Pacella, B. (1948). Labile diabetes: Electroencephalographic status and effect of anticonvulsive therapy. Annals of Internal Medicine, 29, 860-877.

Fairclough, S. H., \& Houston, K. (2004). A metabolic measure of mental effort. Biological Psychology, 66, 177-190. doi:10.1016/j.biopsycho.2003.10.001

Finkel, E. J., \& Campbell, W. K. (2001). Self-control and accommodation in close relationships: An interdependence analysis. Journal of Personality and Social Psychology, 81, 263-277. doi:10.1037/0022-3514.81.2.263

Fisch, H. U., Frey, S., \& Hirsbrunner, H. P. (1983). Analyzing nonverbal behavior in depression. Journal of Abnormal Psychology, 92, 307-318. doi:10.1037/0021-843X.92.3.307

Francis, L. J. (1998). Happiness is a thing called stable extraversion: A further examination of the relationship between the Oxford Happiness Inventory and Eysencks dimensional model of personality and gender. Personality and Individual Differences, 26, 5-11. doi:10.1016/S0191-8869(98)00185-8

Francis, L. J., \& Lester, D. (1997). Religion, personality and happiness. Journal of Contemporary Religion, 12, 81-86. doi:10.1080/13537909708580791

Francis, L. J., Brown, L. B., Lester, D., \& Philipchalk, R. (1998). Happiness as stable extraversion: A cross-cultural examination of the reliability and validity of the Oxford Happiness Inventory among students in the UK, USA, Australia, and Canada. Personality and Individual Differences, 24, 167-171. doi:10.1016/S0191-8869(97)00170-0

French, S., \& Joseph, S. (1999). Religiosity and its association with happiness, purpose in life, and self-actualisation. Mental Health, Religion, and Culture, 2, 117-120. doi:10.1080/13674679908406340

Frey, B. S., \& Stutzer, A. (2000). Happiness prospers in democracy. Journal of Happiness Studies, 1, 79-102. doi: 10.1023/A:1010028211269

Frey, B. S., \& Stutzer, A. (2000). Happiness, economy and institutions. The Economic Journal, 110, 918-938. doi:10.1111/1468-0297.00570

Fris, R., \& Nanjundappa, G. (1986). Diabetes, depression, and employment status. Social Science and Medicine, 23, 471-475. doi:10.1016/0277-9536(86)90006-7

Fugl-Meyer, A. R., Branholm, I.-B., \& Fugl-Meyer, K. (1991). Happiness and domain-specific life satisfaction in adult northern Swedes. Clinical Rehabilitation, 5, 25-33. doi:10.1177/026921559100500105

Furnham, A., \& Cheng, H. (1999). Personality as predictor of mental health and happiness in the east and west. Personality and Individual Differences, 27, 395-403. doi:10.1016/S0191-8869(98)00250-5

Furnham, A., \& Petrides, K. V. (2003). Trait emotional intelligence and happiness. Social Behaviour and Personality, 31, 815-824. doi:10.2224/sbp.2003.31.8.815

Gailliot, M. T. (2008). Unlocking the energy dynamics of executive functioning: Linking executive functioning to brain glycogen. Perspectives on Psychological Science, 3, 245-263. doi:10.1111/j.1745-6924.2008.00077.x

Gailliot, M. T. (2009a). Effortful outgroup interactions impair selfcontrol via the depletion of glucose: The control of stereotypical thought and prejudice as metabolically expensive. Submitted.

Gailliot, M. T. (2009a). The effects of glucose drinks on self-control are not due to the taste of the drink: Glucose drinks replenish self-control. Manuscript under Review.

Gailliot, M. T. (2009b). Hunger impairs and food improves self-control in the laboratory and across the world: Reducing world hunger as a self-control panacea. Submitted

Gailliot, M. T. (2009c). An increased correspondence bias with low blood-glucose: Low glucose increases heuristic thought. Manuscript under Review.

Gailliot, M. T. (2009d). Improved self-control associated with using relatively large amounts of glucose: Learning self-control is metabolically expensive. Submitted.

Gailliot, M. T. (2009e). Alcohol consumption reduces effortful fatigue after sleep: Testing a theory of metabolite depletion and subsequent supercompensation. Submitted.

Gailliot, M. T. (in Press). Mortality salience and metabolism: Glucose drinks reduce worldview defense caused by mortality salience. Psycology.

Gailliot, M. T., \& Baumeister, R. F. (2007). The physiology of willpower: Linking blood glucose to self-control. Personality and Social Psychology Review, 11, 303-327. doi:10.1177/1088868307303030

Gailliot, M. T. (2009). Using self-control makes people feel things more. In Preparation.

Gailliot, M. T., Baumeister, R. F., DeWall, C. N., Maner, J. K., Plant, E. A., Tice, D. M., Brewer, L. E., \& Schmeichel, B. J. (2007). Selfcontrol relies on glucose as a limited energy source: Willpower is more than a metaphor. Journal of Personality and Social Psychology, 92, 325-336. doi:10.1037/0022-3514.92.2.325

Gailliot, M. T., Hildebrandt, B., Eckel, L. A., \& Baumeister, R. F. (2010). A theory of limited metabolic energy and premenstrual syndrome (PMS) symptoms - Increased metabolic demands during the luteal phase divert metabolic resources from and impair selfcontrol. Review of General Psychology, 14, 269-282. doi: $10.1037 / \mathrm{a} 0018525$

Gailliot, M. T., Peruche, B. M., Plant., E. A., \& Baumeister, R. F. (2009). Stereotypes and prejudice in the blood: Sucrose drinks reduce prejudice and stereotyping. Journal of Experimental Social Psychology, 45, 288-290. doi:10.1016/j.jesp.2008.09.003

Gailliot, M. T., Schmeichel, B. J., \& Baumeister, R. F. (2006). Selfregulatory processes defend against the threat of death: Effects of self-control depletion and trait self-control on thoughts and fears of dying. Journal of Personality and Social Psychology, 91, 49-62. doi:10.1037/0022-3514.91.1.49

Gailliot, M. T., Schmeichel, B. J., \& Maner, J. K. (2007). Differentiating the effects of self-control and self-esteem on reactions to mortality salience. Journal of Experimental Social Psychology, 43, 894-901. doi:10.1016/j.jesp.2006.10.011

Gallup (2008). Gallup poll. http://media.gallup.com/poll/graphs/080605Happiness-Stress2_FGF_ ra.gif

Gardner, J., \& Oswald, A. (2001). Does money buy happiness? A longitudinal study using data on windfalls. Royal Economic Society. URL (last checked 13 May 2009).

http://www2.warwick.ac.uk/fac/soc/economics/research/workingpap ers/publications/2006/twerp_754.pdf

George, B. J. (2009). A review of treatment approaches to pre-menstrual syndrome-What do British women perceive to be effective for their symptoms? URL (last checked 7 May 2009). http://www.lifemedicineclinic.com/downloads/premenstrual.pdf

George, M. S., Ketter, T. A., Parekh, P. I., Horwitz, B., Herscovitch, P., \& Post, R. M. (1995). Brain activity diring transient sadness and happiness in healthy women. American Journal of Psychiatry, 152, 341-351.

Gerdtham, U. G., \& Johannesson, M. (2002). The relationship between happiness, health, and socio-economic factors: Results based on Swedish microdata. Journal of Socio-Economics, 30, 553-557. doi:10.1016/S1053-5357(01)00118-4

Gibbs, I., \& Sinclair, I. (2000). Bullying, sexual harassment and happiness in residential children's homes. Child Abuse Review, 9, 247-256. doi:10.1002/1099-0852(200007/08)9:4<247::AID-CAR619>3.3.CO; $2-\mathrm{H}$

Gilliland, M. W. (1978). Energy analysis: A new public policy tool. Boulder, CO: Westview Press.

Gladwell, M. (2009). Outliers. New York: Little, Brown, and Company.

Glenn, N. D., \& McLanahan, S. (1982). Children and marital happiness: 
A further specification of the relationship. Journal of Marriage and the Family, 44, 387-398. doi:10.2307/351263

Glenn, N. D., \& Weaver, C. N. (1978). A multivariate, multisurvey study of marital happiness. Journal of Marriage and the Family, 40, 269-282. doi: $10.2307 / 350758$

Gold, A. E., MacLeod, K. M., Deary, I. J., \& Frier, B. M. (1995). Hypoglycemia-induced cognitive dysfunction in diabetes mellitus: Effect of hypoglycemia unawareness. Physiology and Behavior, 58, 501-511. doi:10.1016/0031-9384(95)00085-W

Gonder-Frederick, L. A., Cox, D. J., Bobbitt, S. A., \& Pennebaker, J. W. (1989). Mood changes associated with blood glucose fluctuations in insulin-dependent diabetes mellitus. Health Psychology, 8, 45-49. doi:10.1037/0278-6133.8.1.45

Gordijn, E. H., Hindriks, I., Koomen, W., Dijksterhuis, A., \& Van Knippenberg, A. (2004). Consequences of stereotype suppression and internal suppression motivation: A self-regulation approach. Personality and Social Psychology Bulletin, 30, 212-224. doi:10.1177/0146167203259935

Graham, C., \& Pettinato, S. (2001). Happiness, markets, and democracy: Latin America in comparative perspective. Journal of Happiness Studies, 2, 237-268. doi:10.1023/A:1011860027447

Griesinger, W. (1876). Die pathologie und therapie der psychischen krankheiten. Braunschweig: Wreden.

Grinde, B. (2002). Happiness in the perspective of evolutionary psychology. Journal of Happiness Studies, 3, 331-354. doi:10.1023/A:1021894227295

Gundelach, P., \& Kreinar, S. (2004). Happiness and life satisfaction in advanced European countries. Cross-Cultural Research, 38, 359-386. doi:10.1177/1069397104267483

Haber, R. N., \& Hershenson, M. (1965). The effects of repeated brief exposures on growth of a percept. Journal of Experimental Psychology, 69, 40-46. doi:10.1037/h0021572

Hagerty, M. R. (2000). Social comparisons of income in one's community: Evidence from national surveys of income and happiness. Journal of Personality and Social Psychology, 78, 764-771. doi:10.1037/0022-3514.78.4.764

Hagerty, M. R., \& Veenhoven, R. (2003). Wealth and happiness revisited-Growing national income does go with greater happiness. Social Indicators Research, 64, 1-27. doi:10.1023/A:1024790530822

Halberstadt, J., \& Rhodes, G. (2000). The attractiveness of nonface averages: Implications for an evolutionary explanation of the attractiveness of average faces. Psychological Science, 4, 285-289. doi: $10.1111 / 1467-9280.00257$

Haller, M., \& Hadler, M. (2006). How social relations and structures can produce happiness and unhappiness: An international comparative analysis. Social Indicators Research, 75, 169-216. doi:10.1007/s11205-004-6297-y

Hamer, D. H. (1996). The heritability of happiness. Nature Genetics, 14, 125-126. doi:10.1038/ng1096-125

Harrison, A. A. (1977). Mere exposure. In L. Berkowitz (Ed.), Advances in experimental social psychology (pp. 39-83). New York: Academic Press.

Hartlage, S. A., \& Arduino, K. E. (2002). Toward the content validity of premenstrual dysphoric disorder: Do anger and irritability more than depressed mood represent treatment-seekers' experiences? Psychological Reports, 90, 189-202. doi:10.2466/pr0.2002.90.1.189

Hartog, J., \& Oosterbeek, H. (1998). Health, wealth and happiness: Why pursue a higher education? Economics of Education Review, 17, 245-256. doi:10.1016/S0272-7757(97)00064-2

Haybron, D. M. (2008). Happiness, the self and human flourishing. Utilitas, 20, 21-49. doi:10.1017/S0953820807002889

Hepburn, D. A., Deary, I. J., MacLeod, K. M., \& Frier, B. M. (1996). Adrenaline and psychometric mood factors: A controlled case study of two patients with bilateral adrenalectomy. Personality and Individual Differences, 20, 451-455. doi:10.1016/0191-8869(95)00191-3

Hessemer, V., \& Bruck, K. (1985). Influence of menstrual cycle on thermoregulatory, metabolic, and heart rate responses to exercise at night. Journal of Applied Physiology, 59, 1911-1917

Hills, P., \& Argyle, M. (2001). Happiness, introversion-extraversion and happy introverts. Personality and Individual Differences, 30, 595-608. doi:10.1016/S0191-8869(00)00058-1
Holahan, C. K., Holahan, C. J., Velasquez, K. E., \& North, R. J. (2008). Longitudinal change in happiness during aging: The predictive role of positive expectancies. The International Journal of Aging and Human Development, 66, 229-241. doi:10.2190/AG.66.3.d

Jacoby, L. L., \& Dallas, M. (1981). On the relationship between autobiographical memory and perceptual learning. Journal of Experimental Psychology: General, 110, 306-340. doi:10.1037/0096-3445.110.3.306

James, G. D., Yee, L. S., Harshfield, G. A., Blank, S. G., \& Pickering, T. G. (1986). The influence of happiness, anger, and anxiety on the blood pressure of borderline hypertensives. Psychosomatic Medicine, 48, 502-508.

Johnson, W., \& Krueger, R. F. (2006). How money buys happiness: Genetic and environmental processes linking finances and life satisfaction. Journal of Personality and Social Psychology, 90, 680-691. doi:10.1037/0022-3514.90.4.680

Johnstone, R. A. (1994). Female preference for symmetrical males as a by-product of selection for mate recognition. Nature, 372, 172-175. doi: $10.1038 / 372172 \mathrm{a} 0$

Jonas, E., \& Fischer, P. (2006). Terror management and religion: Evidence that intrinsic religiousness mitigates worldview defense following mortality salience. Journal of Personality and Social Psychology, 91, 553-567. doi:10.1037/0022-3514.91.3.553

Jopp, D., \& Rott, C. (2006). Adaptation in very old age: Exploring the role of resources, beliefs, and attitudes for centenarians' happiness. Psychology and Aging, 21, 266-280. doi: $10.1037 / 0882-7974.21 .2 .266$

Joseph, S., \& Lewis, C. A. (1998). The depression-happiness scale: Reliability and validity of a bipolar self-report scale. Journal of Clinical Psychology, 54, 537-544.

doi:10.1002/(SICI)1097-4679(199806)54:4<537::AID-JCLP15>3.0. CO;2-G

Kammann, R., \& Flett, R. (1983). Affectometer 2: A scale to measure current level of general happiness. Australian Journal of Psychology, 35, 259-265. doi:10.1080/00049538308255070

Kehle, T. J., \& Bray, M. A. (2003). RICH theory: The promotion of happiness. Psychology in the Schools, 41, 43-49. doi: $10.1002 /$ pits. 10137

Kraepelin, E. (1913). Psychiatrie-Ein lehrbuch fur studierende und aerzte. Leipzig: Barth.

Landgren, B. M., Unden, A. L., \& Diczfalusy, E. (1980). Hormonal profile of the cycle in 68 normally menstruating women. Acta Endocrinologia, 94, 89-98.

Lane, R. E. (1994). The road not taken: Friendship, consumerism, and happiness. Critical Review, 8, 521-554. doi: $10.1080 / 08913819408443359$

Lane, R. E. (2000). Diminishing returns to income, companionship and happiness. Journal of Happiness Studies, 1, 103-119. doi:10.1023/A:1010080228107

Langlois, J. H., \& Roggman, L. A. (1990). Attractive faces are only average. Psychological Science, 1, 115-121. doi:10.1111/j.1467-9280.1990.tb00079.x

Leary, M. R., \& Baumeister, R. F. (2000). The nature and function of self-esteem: Sociometer theory. Advances in Experimental Social Psychology, 32, 1-62. doi:10.1016/S0065-2601(00)80003-9

Leith, K. P., \& Baumeister, R. F. (1996). Why do bad moods increase self-defeating behavior? Emotion, risk taking, and self-regulation. Journal of Personality and Social Psychology, 71, 1250-1267. doi:10.1037/0022-3514.71.6.1250

Lelkes, O. (2005). Tasting freedom: Happiness, religion and economic transition. Journal of Economic Behavior and Organization, 59, 173 194. doi:10.1016/j.jebo.2004.03.016

Lewis, C. A., Lanigan, C., Joseph, S., \& Fockert, J. D. (1997). Religiosity and happiness: No evidence for an association among undergraduates. Personality and Individual Differences, 22, 119-121. doi:10.1016/S0191-8869(97)88910-6

Lewis, C. A., Maltby, J., \& Burkinshaw, S. (2000). Religion and happiness: Still no association. Journal of Beliefs and Values, 21, 233236. doi: $10.1080 / 713675504$

Limosin, F., Gorwood, P., \& Ades, J. (2001). Clinical characteristics of familial versus sporadic alcoholism in a sample of male and female 
patients. European Psychiatry, 16, 151-156.

doi:10.1016/S0924-9338(01)00556-9

Lotka, A. J. (1922). Contribution to the energetics of evolution. Proceedings of the National Academy of Science, 8, 147-151. doi:10.1073/pnas.8.6.147

Lu, L. (1999). Personal or environmental causes of happiness: A longitudinal analysis. The Journal of Social Psychology, 139, 79-90. doi:10.1080/00224549909598363

Lu, L., \& Shih, J. B. (1997). Personality and happiness: Is mental health a mediator? Personality and Individual Differences, 22, 249-256. doi:10.1016/S0191-8869(96)00187-0

Lu, L., \& Shih, J. B. (1997). Sources of happiness: A qualitative approach. The Journal of Social Psychology, 137, 181-187. doi:10.1080/00224549709595429

Lu, L., Shih, J. B., Lin, Y. Y., \& Ju. L. S. (1997). Personal and environmental correlates of happiness. Personality and Individual Differences, 23, 453-462. doi:10.1016/S0191-8869(97)80011-6

Lucas, R. E., Clark, A. E., Georgellis, Y., \& Diener, E. (2003). Reexamining adaptation and the set point model of happiness: Reactions to changes in marital status. Journal of Personality and Social Psychology, 84, 527-539. doi:10.1037/0022-3514.84.3.527

Lustman, P. J., Griffith, L. S., Clouse, R. E., \& Cryer, P. E. (1986). Psychiatric illness in diabetes mellitus: Relationship to symptoms and glucose control. Journal of Nervous and Mental Disease, 174, 736-742. doi:10.1097/00005053-198612000-00005

Lykken, D., \& Tellegen, A. (2006). Happiness is a stochastic phenomenon. Psychological Science, 7, 186-189. doi:10.1111/j.1467-9280.1996.tb00355.x

Lyubomirsky, S., King, L., \& Diener, E. (2005). The benefits of frequent positive affect: Does happiness lead to success? Psychological Bulletin, 131, 803-855. doi:10.1037/0033-2909.131.6.803

Lyubomirsky, S., Sheldon, K. M., \& Schkade, D. (2005). Pursuing happiness: The architecture of sustainable change. Review of General Psychology, 9, 111-131. doi:10.1037/1089-2680.9.2.111

Manusov, E. G., Carr, R. J., Rowane, M., Beatty, L. A., \& Nadeau, M. T. (1995). Dimensions of happiness: A qualitative study of family practice residents. The Journal of the American Board of Family Practice, 8, 367-375.

Marinic, M., \& Brkljacic, T. (2008). Love over gold-The correlation of happiness level with some life satisfaction factors between persons with and without physical disability. Journal of Developmental and Physical Disabilities, 20, 527-540. doi:10.1007/s10882-008-9115-7

Martindale, C. \& Moore, K. (1988). Priming, prototypicality, and preference. Journal of Experimental Psychology: Human Perception and Performance, 14, 661-670. doi:10.1037/0096-1523.14.4.661

Masicampo, E. J., \& Baumeister, R. F. (2008). Toward a physiology of dual-process reasoning and judgment: Lemonade, willpower, and expensive rule-based analysis. Psychological Science, 19, 255-260. doi:10.1111/j.1467-9280.2008.02077.x

Mathes, E. W., \& Kahn, A. (1975). Physical attractiveness, happiness, neuroticism, and self-esteem. Journal of Psychology, 90, 27-30. doi:10.1080/00223980.1975.9923921

Mathieu, S. I. (2008). Happiness and humor group promotes life satisfaction for senior center participants. Activities, Adaptation, and Aging, 32, 134-148. doi:10.1080/01924780802143089

Matsubayashi, K., Kimura, S., Iwasaki, T., Okumiya, S., Hamada, T., Fujisawa, M. et al. (1992). Evaluation of subjective happiness in the elderly using a visual analogue scale of happiness in correlation with depression scale. Nippon Ronen Iqakkai Zasshi, 29, 811-816. doi:10.3143/geriatrics.29.811

Mayo, J. L. (1997). Premenstrual Syndrome: A natural approach to management. Applied Nutritional Science Reports, 5, 1-8.

McCrimmon, R. J., Frier, B. M., \& Deary, I. J. (1999). Appraisal of mood and personality during hypoglycemia in human subjects. Physiology and Behavior, 67, 27-33.

doi:10.1016/S0031-9384(99)00035-9

McGreal, R., \& Joseph, S. (1993). The depression-happiness scale. Psychological Reports, 73, 1279-1282. doi:10.2466/pr0.1993.73.3f.1279

McLanahan, S., \& Adams, J. (1987). Parenthood and psychological well-being. Annual Review of Sociology, 13, 237-257. doi:10.1146/annurev.so.13.080187.001321

Michalos, A. C. (1980). Satisfaction and happiness. Social Indicators Research, 8, 385-422. doi:10.1007/BF00461152

Michalos, A. C. (1983). Satisfaction and happiness in a rural northern resource community. Social Indicators Research, 13, 225-252. doi:10.1007/BF00318099

Mihalce, R., \& Liu, H. (2006). A corpus-based approach to finding happiness.

http://web.media.mit.edu/ hugo/publications/papers/CAAW2006-ha ppiness.pdf

Moller, V., \& Jackson, A. (1997). Perceptions of service delivery and happiness. Development Southern Africa, 14, 169-184. doi:10.1080/03768359708439958

Mookherjee, H. N. (1998). Perception of happiness among elderly persons in metropolitan USA. Perceptual and Motor Skills, 87, 787793. doi:10.2466/pms.1998.87.3.787

Moore, B. S., Clybrun, A., \& Underwood, B. (1976). The role of affect in delay of gratification. Child Development, 47, 273-276. doi: $10.2307 / 1128312$

Mueller, P. S., Heninger, G. R., \& McDonal, R. K. (1968). Intravenous glucose tolerance test in depression. Archives of General Psychiatry, 21, 470-477. doi:10.1001/archpsyc.1969.01740220086010

Mukherjee, D., \& Basu, S. (2008). Correlates of happiness among young adults. National Academy of Psychology, India, 53, 67-71.

Mulder, G. (1986). The concept and measurement of mental effort. In G. R. J. Hockey, A. W. K. Gaillard, M. G. H. Coles (Eds.), Energetical issues in research on human information processing (pp. 175-198). Dordrecht, The Netherlands: Martinus Nijhoff. doi:10.1007/978-94-009-4448-0 12

Muraven, M., \& Slessareva, E. (2003). Mechanisms of self-control failure: Motivation and Limited Resources. Personality and Social Psychology Bulletin, 29, 894-906. doi: $10.1177 / 0146167203029007008$

Muraven, M., Tice, D. M., \& Baumeister, R. F. (1998). Self-control as a limited resource: Regulatory depletion patterns. Journal of Personality and Social Psychology, 74, 774-789. doi: $10.1037 / 0022-3514.74 .3 .774$

Namazie, C., \& Sanfey, P. (1998). Happiness in transition: The case of Kyrgyzstan. Review of Developmental Economics, 5, 392-405. doi:10.1111/1467-9361.00131

Natale, V., \& Albertazzi, P. (2006). Mood swings across the menstrual cycle: A comparison between oral contraceptive users and non-users. Biological Rhythm Research, 37, 489-495. doi: $10.1080 / 09291010600772451$

Natvig, G. K., Albrektsen, G., \& Qvarnstrom, U. (2003). Associations between psychosocial factors and happiness among school adolescents. International Journal of Nursing Practice, 9, 166-175. doi:10.1046/j.1440-172X.2003.00419.x

Nesse, R. M. (2004). Natural selection and the elusiveness of happiness. Philosophical Transactions of the Royal Society of London B, 359, 1333-1347. doi:10.1098/rstb.2004.1511

Neto, F. (2001). Personality predictors of happiness. Psychological Reports, 88, 817-824. doi:10.2466/pr0.2001.88.3.817

Nicolson, P. (1999). Loss, happiness and postpartum depression: The ultimate paradox. Canadian Psychology, 40, 162-178. doi: $10.1037 / \mathrm{h} 0086834$

North, R. J., Holahan, C. J., Moos, R. H., \& Cronkite, R. C. (2008). Family support, family income, and happiness: A 10-year perspective. Journal of Family Psychology, 22, 475-483. doi:10.1037/0893-3200.22.3.475

Odum, H. T. (1995). Self-organization and maximum empower. In C. A. S. Hall (Ed.), Maximum power: The ideas and applications of $H$. T. Odum. Colorado: Colorado University Press.

Orden, S. R., \& Bradburn, N. M. (1969). Working wives and marriage happiness. American Journal of Sociology, 74, 392-407. doi:10.1086/224664

Ortega, S. T., Whitt, H. P., \& Williams, J. A. (1988). Religious homogamy and marital happiness. Journal of Family Issues, 9, 224-239. doi:10.1177/019251388009002005

Oswald, A., \& Powdthavee, N. (2008). Death, happiness, and the calculation of compensatory damages. The Journal of Legal Studies, 37, 
217-251. doi:10.1086/595674

Oswald, A. J., \& Powdthavee, N. (2008). Does happiness adapt? A longitudinal study of disability with implications for economists and judges. Journal of Public Economics, 92, 1061-1077.

doi:10.1016/j.jpubeco.2008.01.002

Palmer, S. E. (1991). Goodness, gestalt, groups, and garner: Local symmetry subgroups as a theory of figural goodness. In J. R. Pomerantz, \& G. R. Lockhead (Eds.), Perception of structure (pp. 23-40). Washington DC: American Psychological Association.

Park, N., \& Peterson, C. (2006). Character strengths and happiness among young children: Content analysis of parental descriptions. Journal of Happiness Studies, 7, 323-341.

doi:10.1007/s10902-005-3648-6

Perneger, T. V., Hudelson, P. M., \& Bovier, P. A. (2004). Health and happiness in young Swiss adults. Quality of Life Research, 13, 171178. doi:10.1023/B:QURE.0000015314.97546.60

Peterson, C., Ruch, W., Beermann, U., Park, N., \& Seligman, M. E. P. (2007). Strengths of character, orientations to happiness, and life satisfaction. The Journal of Positive Psychology, 2, 149-156. doi:10.1080/17439760701228938

Phillips, D. L. (1967). Mental health status, social participation, and happiness. Mental Health and Happiness, 72, 479-488.

Phillips, D. L. (1967). Social participation and happiness. American Journal of Sociology, 72, 479-488. doi:10.1086/224378

Pickford, J. H., Signori, E. I., \& Rempel, H. (1966). Similar of related personality traits as a factor in marital happiness. Journal of Marriage and the Family, 28, 191-192. doi:10.2307/349280

Pina, D. L., \& Bengtson, V. L. (1993). The division of household labor and wives' happiness: Ideology, employment, and perceptions of support. Journal of Marriage and the Family, 55, 901-912. doi: $10.2307 / 352771$

Popkin, M. K., Callies, A. L., Lentz, R. D., Colon, E. A., \& Sutherland, D. E. (1988). Prevalence of major depression, simple phobia, and other psychiatric disorders in patients with long standing type I diabetes mellitus. Archives of General Psychiatry, 45, 64-68. doi:10.1001/archpsyc.1988.01800250078010

Posner, M. I., \& Keele, S. W. (1968). On the genesis of abstract ideas. Journal of Experimental Psychology, 77, 353-363. doi: $10.1037 / \mathrm{h} 0025953$

Rabin, C., \& Shapira-Berman, O. (1997). Egalitarianism and marital happiness: Israeli wives and husbands on a collision course? The American Journal of Family Therapy, 25, 319-330. doi:10.1080/01926189708251076

Rapkin, A. (2003). A review of treatment of premenstrual syndrome \& premenstrual dysphoric disorder. Psychoneuroendocrinology, 28, 3953. doi:10.1016/S0306-4530(03)00096-9

Reber, R., Winkielman, P., \& Schwarz, N. (1998). Effects of perceptual fluency of affective judgments. Psychological Science, 9, 45-48. doi: 10.1111/1467-9280.00008

Reid, M., \& Hammersley, R. (1995) Effects of carbohydrate intake on subsequent food intake and mood state. Physiology and Behavior, 58, 421-427. doi:10.1016/0031-9384(95)00075-T

Rhodes, G., \& Tremewan, T. (1996). Averageness, exaggeration, and facial attractiveness. Psychological Science, 7, 105-110. doi:10.1111/j.1467-9280.1996.tb00338.x

Rogers, S. J., \& DeBoer, D. D. (2001). Changes in wives' income: Effects of marital happiness, psychological well-being, and the risk of divorce. Journal of Marriage and the Family, 63, 458-472. doi:10.1111/j.1741-3737.2001.00458.x

Rosch, E., \& Lloyd, B. B. (1978). Cognition and categorization. Hillsdale, NJ: Erlbaum.

Roysamb, E., Tambs, K., Reichborn-Kjennerud, T., Neale, M. C., \& Harris, J. R. (2003). Happiness and health: Environmental and genetic contributions to the relationship between subjective well-being, perceived health, and somatic illness. Journal of Personality and Social Psychology, 85, 1136-1146. doi:10.1037/0022-3514.85.6.1136

Rubinow, D. R., Roy-Byrne, P., Hoban, M. C., Grover, G. N., Stambler, N., \& Post, R. M. (1986). Premenstrual mood changes. Characteristic patterns in women with and without premenstrual syndrome. Journal of Affective Disorders, 10, 85-90.

doi:10.1016/0165-0327(86)90030-3
Ryuichi, K., Takaaki, D., Akihiro, Y., Masanobu, O., Koki, T., Motomi, S., \& Eiji, K. (1999). Happiness and background factors in community-dwelling older persons. Japanese Journal of Geriatrics, 36, 861867. doi:10.3143/geriatrics. 36.861

Saunders, P. (2009). Income, health, and happiness. Ideas. URL (last checked 21 May 2009).

http://ideas.repec.org/a/bla/ausecr/v29y1996i4p353-366.html

Schmeichel, B. J., Vohs, K. D., \& Baumeister, R. F. (2003). Intellectual performance and ego depletion: Role of the self in logical reasoning and other information processing. Journal of Personality and Social Psychology, 85, 33-46. doi:10.1037/0022-3514.85.1.33

Schmeichel, B. J., Demaree, H. A., Robinson, J. L., \& Pu, J. (2006). Ego depletion by response exaggeration. Journal of Experimental Social Psychology, 42, 95-102. doi:10.1016/j.jesp.2005.02.005

Scholey, A. B., \& Kennedy, D. O. (2004). Cognitive and physiological effects of an "energy drink": An evaluation of the whole drink and of glucose, caffeine and herbal flavouring fractions. Psychopharmacology, 17, 320-330. doi:10.1007/s00213-004-1935-2

Schwartz, B., Ward, A., Monterosso, J., Lyubomirsky, S., White, K., \& Lehman, D. R. (2002). Maximizing versus satisficing: Happiness is a matter of choice. Journal of Personality and Social Psychology, 83, 1178-1197. doi:10.1037/0022-3514.83.5.1178

Schwarz, J. C., \& Pollack, P. R. (1977). Affect and delay of gratification. Journal of Research in Personality, 11, 147-164. doi:10.1016/0092-6566(77)90013-7

Schyns, P. (1998). Crossnational differences in happiness: Economic and cultural factors explored. Social Indicators Research, 43, 3-26. doi:10.1023/A:1006814424293

Selim, S. (2008). Life satisfaction and happiness in Turkey. Social Indicators Research, 88, 531-562. doi:10.1007/s11205-007-9218-Z

Shamosh, N. A., \& Gray, J. R. (2007). The relation between fluid intelligence and self-regulatory depletion. Cognition and Emotion, 21, 1833-1843. doi:10.1080/02699930701273658

Shin, D. C., \& Johnson, D. M. (1978). Avowed happiness as an overall assessment of the quality of life. Social Indicators Research, 5, 475492. doi:10.1007/BF00352944

Singh, N. N., Lancioni, G. E., Winton, A. S. W., Wahler, R. G., Singh, J., \& Sage, M. (2004). Mindful caregiving increases happiness among individuals with profound multiple disabilities. Research in Developmental Disabilities, 25, 207-218. doi:10.1016/j.ridd.2003.05.001

Smith, A. P., Clarka, R., \& Gallaghera, J. (1999). Breakfast cereal and caffeinated coffee effects on working memory, attention, mood, and cardiovascular function. Physiology \& Behavior, 67, 9-17. doi:10.1016/S0031-9384(99)00025-6

Solomon, S. J., Kurzer, M. S., \& Calloway, D. H. (1982). Menstrual cycle and basal metabolic rate in women. The American Journal of Clinical Nutrition, 36, 611-616.

Stack, S., \& Eshleman, J. R. (1998). Marital status and happiness: A 17-nation study. Journal of Marriage and Family, 60, 527-536. doi: $10.2307 / 353867$

Steel, P., \& Ones, D. S. (2002). Personality and happiness: A nationallevel analysis. Journal of Personality and Social Psychology, 83, 767-781. doi:10.1037/0022-3514.83.3.767

Storm, C. (1996). Aspects of meaning in words related to happiness. Cognition and Emotion, 10, 279-302. doi:10.1080/026999396380259

Stutzer, A. (2004). The role of income aspirations in individual happiness. Journal of Economic Behavior and Organization, 54, 89-109. doi:10.1016/j.jebo.2003.04.003

Suitor, J. J. (1987). Marital happiness of returning women students and their husbands: Effects of part and full-time enrollment. Research in Higher Education, 27, 311-331. doi:10.1007/BF00991661

Swinyard, W. R., Kau, A.-K., \& Phua, H.-Y. (2001). Happiness, materialism, and religious experience in the US and Singapore. Journal of Happiness Studies, 2, 13-32. doi:10.1023/A:1011596515474

Symonds, C. S., Gallagher, P., Thompson, J. P., \& Young, A. H. (2004). Effects of the menstrual cycle on mood, neurocognitive and neuroendocrine function in healthy premenopausal women. Psychological Medicine, 34, 93-102. doi:10.1017/S0033291703008535

Taylor, L. A. \& Rachman. S. J. (1988). The effects of blood sugar level changes on cognitive function, affective state, and somatic symptoms. 


\section{T. GAILLIOT}

Journal of Behavioral Medicine, 11, 279-291. doi:10.1007/BF00844433

Tella, R. D., \& MacCulloch, R. (2007). Gross national happiness as an answer to the Easterlin Paradox? Journal of Developmental Economics, 86, 22-42. doi:10.1016/j.jdeveco.2007.06.008

Tella, R. D., MacCulloch, R. J., \& Oswald, A. J. (2003). The macroeconomics of happiness. The Review of Economics and Statistics, 85, 809-827. doi: $10.1162 / 003465303772815745$

Tella, R. D., New, J. H.-D., \& MacCulloch, R. (2007). Happiness adaptation to income and to status in an individual panel. URL (last checked 13 May 2009). http://ssrn.com/abstract=992162

Tice, D. M., Baumeister, R. F., Shmueli, D., \& Muraven, M. (2007). Restoring the self: Positive affect helps improve self-regulation following ego depletion. Journal of Experimental Social Psychology, 43, 379-384. doi:10.1016/j.jesp.2006.05.007

Tice, D. M., Bratslavsky, E., \& Baumeister, R. F. (2001). Emotional distress regulation takes precedence over impulse control: If you feel bad, do it! Journal of Personality and Social Psychology, 80, 53-67. doi:10.1037/0022-3514.80.1.53

Tkach, C., \& Lyubomirsky, S. (2006). How do people pursue happiness? Relating personality, happiness-increasing strategies, and well-being. Journal of Happiness Studies, 7, 183-225. doi:10.1007/s10902-005-4754-1

Tsou, M. W., \& Liu, J. T. (2001). Happiness and domain satisfaction in Taiwan. Journal of Happiness Studies, 2, 269-288. doi:10.1023/A:1011816429264

Uchida, Y., Norasakkunkit, V., \& Kitayama, S. (2004). Cultural constructions of happiness: Theory and empirical evidence. Journal of Happiness Studies, 5, 223-239. doi:10.1007/s10902-004-8785-9

Van Pragg, H. M., \& Leijnse, B. (1965). Depression, glucose tolerance, peripheral glucose uptake and their alterations under the influence of anti-depressive drugs of the hydrazine type. Psychopharmacologica, 8, 67-78. doi:10.1007/BF00405362

Veenhoven, R. (1988). The utility of happiness. Social Indicators Research, 20, 333-354. doi:10.1007/BF00302332

Veenhoven, R. (1991). Is happiness relative? Social Indicators Research, 24, 1-34. doi:10.1007/BF00292648

Vohs, K. D., Baumeister, R. F., \& Ciarocco, N. J. (2005). Self-regulation and self-presentation: Regulatory resource depletion impairs impression management and effortful self-presentation depletes regulatory resources. Journal of Personality and Social Psychology, 88, 632-657. doi:10.1037/0022-3514.88.4.632

Ward, R. A. (1993). Marital happiness and household equity in later life. Journal of Marriage and Family, 55, 427-438. doi:10.2307/352813

Webb, P. (1981). Increased levels of energy exchange in women after ovulation. The Physiologist, 24, 43.

Webb, P. (1986). 24-hour energy expenditure and the menstrual cycle. The American Journal of Clinical Nutrition, 44, 614-619.

Weinhold, D. (2008). How big a problem is noise pollution? A brief happiness analysis by a perturbable economist. URL (last checked 22 May2009).

http://mpra.ub.uni-muenchen.de/10660/2/The utility costs of noise $p$ ollutionv3.pdf

Weiss, A., Bates, T. C., \& Luciano, M. (2008). Happiness is a per- sonal(ity) thing: The genetics of personality and well-being in a representative sample. Psychological Science, 19, 205-210. doi:10.1111/j.1467-9280.2008.02068.x

Wells, K. B., Golding, J. M., \& Burnam, M. A. (1989). Affective substance use, and anxiety disorders in persons with arthritis, diabetes, heart disease, high blood pressure, or chronic lung conditions. General Hospital Psychiatry, 11, 320-327. doi:10.1016/0163-8343(89)90119-9

Welsch, H. (2008). The social costs of civil conflict: Evidence from surveys of happiness. Kyklos, 61, 320-340. doi:10.1111/j.1467-6435.2008.00404.x

White, L. K., Booth, A., \& Edwards, J. N. (1986). Children and marital happiness. Journal of Family Issues, 7, 131-147. doi: $10.1177 / 019251386007002002$

Whittlesea, B. W. A. (1993). Illusions of familiarity. Journal of EXperimental Psychology: Learning, Memory, and Cognition, 19, 1235 1253. doi:10.1037/0278-7393.19.6.1235

Whittlesea, B. W. A., Jacoby, L. L., \& Girard, K. (1990). Illusions of immediate memory: Evidence of an attributional basis for feelings of familiarity and perceptual quality. Journal of Memory and Language, 29, 716-732. doi:10.1016/0749-596X(90)90045-2

Wikipedia (2012). Wikipedia entries for dopamine, acetylcholine, GABA, and glutamate. www.wikipedia.org

Wilson, D. R. (1951). Electroencephalographic studies in diabetes mellitus. Canadian Medical Association Journal, 65, 462-465.

Witherspoon, D., \& Allan, L. G. (1985). The effects of a prior presentation on temporal judgments in a perceptual identification task. Memory and Cognition, 13, 103-111. doi:10.3758/BF03197003

World Bank (1997). World values survey. World Development Report.

Wredling, R. A. M., Theorell, P. G. T., Roll, M. H., Lins, P. E. S., \& Adamson, U. K. C. (1992). Psychosocial state of patients with IDDM prone to recurrent episodes of severe hypoglycemia. Diabetes Care, 75, 518-521. doi:10.2337/diacare.15.4.518

Yaryura-Tobias, J. A., \& Neziroglu, F. A. (1975). Violent behavior, brain dysrhythmia, and glucose dysfunction: A new syndrome. Journal of Orthomolecular Psychiatry, 4, 182-188.

Yu, D. C. T., Spevack, S., Hiebert, R., Martin, T. L., Goodman, R., Martin, T. et al. (2002). Happiness indices among persons with profound and severe disabilities during leisure and work activities: A comparison. Education and Training in Mental Retardation and Developmental Disabilities, 37, 421-426.

Zajonc, R. B. (1968). Attitudinal effects of mere exposure. Journal of Personality and Social Psychology: Monograph Supplement, 9, 1-27. doi: $10.1037 / \mathrm{h} 0025848$

Zajonc, R. B. (2001). Mere exposure: An unmediated process. URL (last checked 5 November 2001). http://citeseerx.ist.psu.edu/viewdoc/summary?doi=10.1.1.23.3462

Zajonc, R. B. (2002). Mere exposure: A gateway to the subliminal. Current Directions in Psychological Science, 10, 224-228. doi:10.1111/1467-8721.00154

Zhao, G., Wang, L., Qu, C., \& Wang, X. (1998). Personality and climacteric syndrome in women. Chinese Mental Health Journal, 12, $163-137$. 